$9-1-1991$

\title{
A Slave's Marriage: Dowry or Deposit
}

\author{
Alan Watson \\ University of Georgia School of Law, wawatson@uga.edu
}

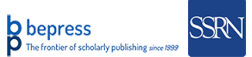

\section{Repository Citation}

Alan Watson, A Slave's Marriage: Dowry or Deposit (1991),

Available at: https://digitalcommons.law.uga.edu/fac_artchop/652

This Article is brought to you for free and open access by the Faculty Scholarship at Digital Commons @ University of Georgia School of Law. It has been accepted for inclusion in Scholarly Works by an authorized administrator of Digital Commons @ University of Georgia School of Law. Please share how you have benefited from this access For more information, please contact tstriepe@uga.edu. 


\section{A Slave's Marriage: Dowry or Deposit}

\section{ALAN WATSON}

A marked characteristic of Roman juristic texts is the absence of any information that is not directly relevant to the ruling. Almost always the only facts stated are those necessary to determine the appropriate legal response, but there are a few exceptional texts and these are usually particularly revealing - for example, D. 16.3.27 (Paul, book seven of Replies) which is the main subject of this article.

A notable feature of Roman contract law derives from the nature of Roman actions: an agreement is a contract only if the form or terms places it within the scope of a particular contractual action such as the actio ex empto, action on purchase, or the actio ex conducto, action on hiring. This, of course, had the consequence, among others, of forcing the development of Roman legal concepts and institutions. If on a transaction you brought the action on sale and it fell to be considered as hire, you lost your case, and after joinder of issue (litis contestatio) no subsequent action could be brought on the same facts. It was thus important in law to determine precisely what was sale, for example, and what was hire.

To alleviate the problems which could arise from this there developed a number of palliatives. One, probably dating from no earlier than the middle of the first century $\mathrm{BC}^{1}$ was to allow in particularly difficult circumstances an action in some form or other on the facts. Another was to allow a transaction that began as one contract to end as another. The type of contract involved depended on the form or function, not on the intention of the parties.

To take an example not evidenced in the sources: if I deliver a slave to you on the basis (a) that you pay me X per year for his services, (b) that if you retain his services for 10 years on these terms you will be entitled to ownership, (c) that you may renounce the contract at any time and return the slave to me, and (d) that at any time if you pay me $10 \mathrm{X}$ you will be entitled to ownership of the slave, then we have an initial contract of hire that may become sale. The best known textual example is $G .3 .146$ :

Again, if I supply you with gladiators on the terms that for each one who emerges uninjured I shall be given 20 denarii for his exertions, for each one who is killed or disabled 1000 denarii, the question

Alan Watson is at the University of Georgia. 
arises whether the contract is sale or hire. The prevailing opinion is that it is hire of those who emerge uninjured, but sale of those killed or disabled. Which it is appears from the events as if there was a conditional sale or hire of each one. For it is no longer doubted that things may conditionally be the object of sale or hire. ${ }^{2}$

The main problem arises, of course, if I simply fail to deliver the gladiators. Then there is no way of telling whether the action should be on sale or hire. One might hope the praetor would grant an action on the facts. ${ }^{3}$

But for us, now, attention should focus on the last sentence of the text, which I believe is usually mistranslated as 'For there is no longer any doubt that things can be sold or hired conditionally' 4 or 'subject to conditions'.5 But there never was any doubt that there could be a conditional sale or a conditional hire. Rather, the text should be treated (as I have translated) as: 'For it is no longer doubted that things may conditionally be the object of sale or hire.' That is, it was accepted by the time of Gaius - and he is usually old-fashioned - that a transaction could change its legal character by the course of events.

For the issues so far raised particular light is shed by texts on the contract of deposit such as D. 16.3.1.11 (Ulpian, Edict, book 30):

If I ask you to take something of mine to Titius for him to look after it, the question is posed by Pomponius as to which action I can bring against you. And he thinks the action against you is on mandate, against the person who received the thing you have the action on deposit, which action you will cede to me when sued on the action on mandate. 12. But if I gave the thing to you on the terms that if Titius did not receive the thing you would look after it, and he did not receive it, we should consider whether there is only an action on deposit or also that on mandate. Pomponius hesitates: but I think the action is mandate because the mandate was wider, including the term of custody. ${ }^{6}$

The decision in $\$ 11$ is clearly correct but it and $\$ 12$ bring out the closeness of mandate and deposit. What matters for us is that the facts including the intention of the parties give rise to a contractual obligation, but it is not the intention of the parties that determines which contract is involved.

To come at last to D. 16.3.27:

When Lucius Titius had a daughter, Seia, in his power (potestas), he gave her in marriage to Pamphilus who was a slave belonging to another. He also gave to Pamphilus a dowry which he set out in a 
written document under the title of a deposit. No denunciation was made by his owner, the father then died, and a little later so did Pamphilus. I ask by what action can Seia sue for the money when she herself was heir to her father. Paul replied, since dowry could not be constituted, the money was to be reclaimed by the action on the peculium on account of deposit. ${ }^{7}$

For the legal decision it was irrelevant that Seia was in the potestas of her father at the time of the 'marriage': it is only relevant that she was her father's heir at the death of Pamphilus. It is this that gave her the right to her father's remedy. Again, there was no need to mention that there was no denuntiatio from Pamphilus's owner. This denuntiatio, as a result of the senatus consultum Claudianum would have made Seia a slave..$^{8}$ Whether there were or were not the appropriate steps for denuntiatio is of course relevant to the parties, but that there were none need not have been mentioned since the legal point of the case could not otherwise have arisen. The most obvious explanation of these unnecessary details is that the issue was an actual, not a hypothetical, one that really was put. Paul's respondit (he replied) indicates a reply to a question that was put to him.

The text is equally interesting from social and legal viewpoints for it is one of those that also reveal how close some slaves might be socially to some free persons. Slaves could not contract a valid marriage. The free pater familias, Lucius Titius, knew that, and he knew that Pamphilus was a slave, yet he was not unwilling that Pamphilus be united with his daughter. We can deduce all this from the stated fact that he wanted to give Pamphilus a dowry which - since he could not - he set out as if it were a deposit. He was attempting to get around the impossibility of a dowry which could not be created in the absence of a marriage. ${ }^{9}$ No dowry was needed for the creation of a Roman marriage, though it was often used as a sign to show that marriage was intended. ${ }^{10}$ Lucius Titius's wish to create a dowry indicates that he wanted to show that he regarded the union as respectable. He also felt warmly enough towards his daughter that she became his heir. More than that, he clearly felt that Pamphilus was a fit person to be entrusted with a dowry. It is a reasonable assumption that Pamphilus was in some way of business, and lived, to some extent at least, independently of his owner. In addition, since Lucius Titius was constituting a 'dowry' he was not among the poorest members of free society.

The basic legal issue is why Paul allowed an action on the peculium, ex causa depositi. There was no marriage, therefore no dowry, therefore no actio rei uxoriae. But that would not justify an action on account of 
depositum. Depositum is something very different from dos. In dowry, ownership was transferred to the husband, as was possession; the dowry was returnable only when the marriage ended, and the recipient was liable for negligence. In deposit, the depositor retained both ownership and possession; the property deposited had to be returned on demand at any time, and the depositee was liable only for fraud.

It cannot be argued either that the action was on deposit simply because the parties created a document that claimed to record a deposit. As we have seen in the introductory pages of this essay, the Roman rule was that an arrangement fell within a particular type of contract only if it corresponded to the typology or substance of that type. ${ }^{11}$ The issue was not affected by what the parties believed or claimed the arrangement to be.

Nor can one believe that Paul was simply sympathetic to Seia, and gave an action on account of deposit because there was no other plausible remedy. On the contrary, in the abstract a condictio would seem to have been a more appropriate remedy. This is so whether one argues that there was the equivalent of mutuum or simply that the requirements for condictio were present. In the second alternative there had been a delivery of property, a datio by Lucius Titius to Pamphilus, and there was no legal justification for retention by Pamphilus's owner. For the former alternative, still talking in the abstract, mutuum was closer to reality than depositum. As with dos, so with mutuum, ownership and possession would be delivered to the recipient. The date of repayment could have been fixed as the time when the marriage ended.12 It is not being argued here, of course, that the condictio was the perfect remedy for Seia, only that it was as appropriate as, and in fact more appropriate than, deposit. Hence we still have to find an explanation for Paul granting an action on deposit.

It seems there is only one remaining possibility, unless one wants to argue, as I would not, that Paul's response was just wrong. That possibility is that Lucius Titius and Pamphilus framed their agreement not just to look like a deposit but to fall within the typology of deposit. Lucius Titius wanted to create a dowry but this was impossible, therefore he sought an alternative arrangement that would have legal effect and thus had to fall within the framework of a particular type of Roman contract, and he selected depositum.

We would thus have to determine what the arrangement that counted as deposit was, why the parties chose it, and the extent to which it could meet the desires of the parties. But first there is an important primary conclusion to be set down. The parties, whether Lucius Titius or Pamphilus or both, were very well aware of what they were doing. 
They could not create a dowry, hence they sought an alternative. They designed a document to record what they did. One obvious function of the document was to provide evidence to Pamphilus's owner of the giving of the dowry in the event of Pamphilus's death. But a further function has now emerged: to give evidence, even for a court in the event of a dispute, of the precise legal nature of the peculiar arrangement. The subtlety and legal sophistication of the parties are revealed.

The arrangement can only have been depositum irregulare which was certainly recognized by the time of Paul. ${ }^{13}$ Ordinary deposit would achieve nothing. It takes property - in this case specifically money out of circulation. The depositee cannot use or make profit out of it. The depositor benefits only because he needs safekeeping for the property. In depositum irregulare the recipient still cannot profit but he uses the money deposited specifically for the benefit of the depositor. ${ }^{14}$ In this instance, Pamphilus is not supposed to benefit from the arrangement but Lucius Titius, or Seia, should. In other words, if we treat the transaction as a deposit, Pamphilus is to use Lucius Titius's money safely, for the benefit of Lucius Titius (or ultimately Seia), not for himself. The conclusion is inescapable. The free Roman, Lucius Titius, trusts the business acumen of Pamphilus the slave. It looks very much as if Pamphilus runs a business and the money handed over represents a
capital investment.

Depositum irregulare is, of course, not dos, but in a situation like this where dos cannot be created, depositum irregulare provides great protection. It is a necessary feature of depositum that the depositee acts gratuitously. Thus, the sum deposited and all income from it accrue to the depositor. In this instance, the precise advantage is that any profits will be there for Lucius Titius or Seia or her heirs. Pamphilus's owner is
legally excluded from any benefit. This is the main practical advantage of
the arrangement, and it further reveals the the arrangement, and it further reveals the legal sophistication of Lucius
Titius and Pamphilus.

But how do the relevant legal differences between dos and depositum irregulare affect the suitability of the arrangement? Depositum had to be returned on request, dos only on the termination of marriage. But divorce was unrestricted and could occur at the wish of one party. The only significant problem here is that Lucius Titius could demand his money back even when Seia and Pamphilus wanted the relationship to continue. In contrast, the action for recovery of dowry, actio rei uxoriae, when the dowry had been given by the wife's father, required the participation of the wife. However, there was no way to circumvent this problem for Pamphilus. Again, the arrangement would come to an unhappy end if during the continuance of the marriage Lucius Titius 
died and Seia was neither his heir (whether on intestacy or under a will) nor was left a legacy of the money deposited. She would have no legal claim for the deposit, whereas simply as wife she would have the actio rei uxoriae on the termination of the marriage. In the case of dowry, the husband (who became owner) was liable both for dolus and culpa; in deposit, the recipient was liable only for dolus. But it was a feature of contract that the parties could alter the standard of liability. 15 If Lucius Titius wished, the cautio could have required that the depositee be liable for culpa. So there was no problem here.16 Finally, at the end of a marriage the husband might be entitled to keep part of the dowry, on account of the wife's misconduct or of the birth of children. There could be no such retention right in the case of depositum. But nor would any be wanted in this situation, at least not for the upkeep of children. Pamphilus was a slave but his children, if any, with Seia (in the absence of a denuntiatio) would be free. It is not appropriate that property for their upkeep be in the ownership of their father's owner rather than be controlled by a free tutor. Nor would a denuntiatio by Pamphilus's owner to Seia adversely affect the financial situation: Lucius Titius or his heir would still be entitled to the return of the deposit.

This cautio for deposit was a stroke of brilliance. For the unmarried 'married couple' the arrangement could have gone wrong, unlike a properly constituted dowry (which in the circumstances was impossible), only if Lucius Titius and Seia had a falling out and he no longer wanted her to benefit from his property or if Lucius Titius had financial problems and he or his creditors called in the deposit. But it gave the couple the social respectability of 'dowry', fulfilled the functions for which dowry was created, and kept the money out of the hands of Pamphilus's owner.

I have observed in other circumstances that the Roman jurists drew horrific conclusions from aspects of slave law, especially of the senatus consultum Silanianum, in exactly the same way as they drew conclusions from more benign law. ${ }^{17}$ Here Paul also approaches the law in an even-handed way. There is no indication that he wished to avoid the agreement as a fraus legis, an attempt to get round the law, though it would have been open to him to do so. There is, thus, no sign of repugnance at a sexual relationship between a slave and a free Roman woman.

There are, indeed, marked signs of sexism in the treatment in law of such relationships, as is noted above. But what has to be stressed for an understanding of Roman law is how little it is marked by a 'public dimension'. The contrast with the southern states of the United States is marked. The recapture of runaway slaves in Rome was entirely a matter 
for the owner, whereas in the US it was regulated by the state. Similarly, here action against a free woman for cohabiting with another's slave was left solely to the slave's owner.

\section{NOTES}

1. Cf. A. Watson, Law Making in the Later Roman Republic, Oxford, 1974, p. 92.

2. 'Item, [quaeritur] si gladiatores ea lege tibi tradiderim, ut in singulos qui integri exierint pro sudore denarii $\mathrm{xx}$ mihi darentur, in eos uero singulos qui occisi aut debilitati fuerint denarii mille, quaeritur utrum emptio et venditio an locatio et conductio contrahatur. et magis placuit eorum qui integri exierint locationem et conductionem contractam videri, at eorum qui occisi aut debilitati sunt emptionem et venditionem esse; idque ex accidentibus apparet, tamquam sub condicione facta cuiusque venditione aut locatione. iam enim non dubitatur quin sub condicione res venire aut locari possint.'

3. See A. Watson, Roman Law and Comparative Law, Athens, GA., 1991, p. 258.

4. F. de Zulueta, Institutes of Gaius 1, Oxford, 1946, p. 199.

5. W.M. Gordon and O.F. Robinson, Institutes of Gaius, London, 1988, p. 349.

6. 'Si te rogavero, ut rem meam perferas ad Titium, ut is eam servet, qua actione tecum experiri possum, apud Pomponium quaeritur, et putat tecum mandati, cum eo vero, qui eas res receperit, depositi: si vero tuo nomine receperit, tu quidem mihi mandati teneris, ille tibi depositi, quam actionem mihi praestabis mandati iudicio conventus. 12. Quod si rem tibi dedi, ut, si Titius rem non recepisset, tu custodires, nec eam recepit, videndum est, utrum depositi tantum an et mandati actio sit. et Pomponius dubitat: puto tamen mandati esse actionem, quia plenius fuit mandatum habens et custodiae legem.' See also D. 16.3.13,14.

7. 'Lucius Titius cum haberet filiam in potestate Seiam, Pamphilo servo alieno in matrimonium collocavit, cui etiam dotem dedit, quam sub titulo depositi in cautionem contulit, et postea nulla denuntiatione a domino facta, pater decessit, mox et Pamphilus servus: quaero, qua actione Seia pecuniam petere possit, cum ipsa patri heres extiterit. Paulus respondit, quoniam dos constitui non potuit, ex causa depositi actione de peculio pecuniam repetendam.'

8. For details see W.W. Buckland, The Roman Law of Slavery, Cambridge, 1908, pp. $412 \mathrm{ff}$. The denuntiatio would not have made Seia a slave if her father was unaware of the marriage: Pauli Sententiae 2.21A.9.

9. P. Voci believes the father was unaware that Pamphilus was a slave: 'Storia della patria potestas da Augusto a Diocleziano', 31 IURA (1980), pp. 37ff at p. 47n.54. This is clearly against the evidence of the text. The mistake occurs because he thinks the father lost patria potestas when he allowed a daughter to commit an immoral act. This is based on his reading of Pauli Sententiae 2.21A.10 which says if a father marries his daughter to another's slave against the wishes of the owner, the daughter becomes a slave. But into that text must be read the self-understood rule that there had to be a denuntiatio.

10. See, for example, P.E. Corbett, The Roman Law of Marriage, Oxford, 1930, p. 152.

11. A further particularly illuminating example is in D. 13.6.13.2.

12. Still, one should also note the differences between mutuum and dos. In the former, Still, one should also note the differences between mutuum and dos. In lost without
the recipient was liable to restore the value of the property even if it was los
fault.

13. See D. 16.3 .1 .34 ; h.t. 24 ; h.t. 25.1 ; h.t. 28 ; h.t. 29.1 ; Coll. 10.7 .9 . Munich, 1971 ,

14. See, for example, M. Kaser, Das römische Privatrecht 1, 2nd ed., Munich, 197, p. 536.

15. See D. 16.3.1.6. 
16. The particular difficulty that since Pamphilus was a slave his owner would be liable to an action only up to the amount of the peculium is irrelevant in a discussion of the differences between dos and depositum as that limitation would exist no matter what arrangement could be made.

17. Slave Law in the Americas, Athens, GA., 1989, pp. 7 ff. 